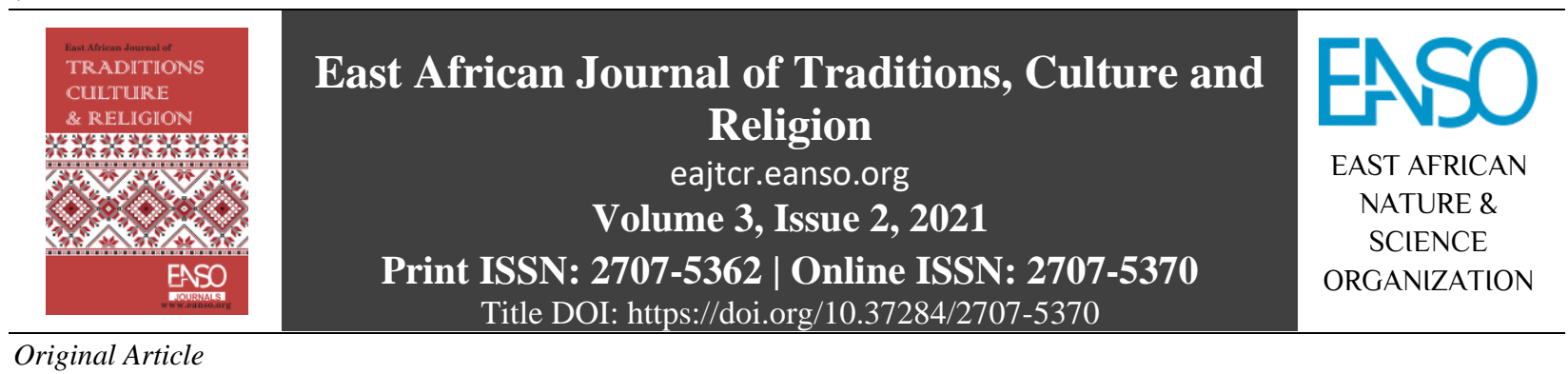

\title{
Inculturation Methodology as the Medium towards the Formulation and Establishment of an African Ecclesiology of Ubuntu.
}

\author{
Peter Lee Ochieng Oduor, PhD \\ ${ }^{1}$ Africa International University, P.O Box 24686, 00502, Nairobi, Kenya. \\ Author Correspondence Email: pastoroduorlee@gmail.com.
}

Article DOI: https://doi.org/10.37284/eajtcr.3.2.369

\section{Date Published: ABSTRACT}

29 July 2021 The emergence of ecclesiology scholarship in recent theological discourse has exposed the various approaches that ecclesiology has been studied as a

Keywords: distinctive discipline. The traditional ecclesiological approach has prioritized the scholarship of ecclesiology from the perspective of specific denominational

Ubuntu, orders. There has also been an approach of ecclesiology that revolves around the Ecclesiology of

Ubuntu, perspective of some renowned theologians on the basis of their affiliation to their respective church organizations. The most recent approach has been the global

Contextualization, ecclesiology that prioritizes the concept of contextualization while looking at ecclesiological discourse from distinct sociocultural-geographical contexts. trajectory of Christianity towards the global South: Asia, Africa and Latin

Culture. America. African ecclesiology plays a critical role in this arrangement and is a major contributor to global ecclesiology. In this understanding, it is imperative for the pursuit of an African ecclesiology to appreciate the concept of Ubuntu as a definitive expression of the African identity. The problem is the methodology of ecclesiological scholarship in Africa that ignores the significance Ubuntu has and resultantly births a foreign ecclesiology to the indigenous African population. It is important to acknowledge that the approach of ecclesiology that will thrive in Africa is nothing less than an Ubuntu ecclesiology that prioritizes community and relationships reminiscent of our traditional African portrait as foundational pillars for her establishment. The formulation and establishment of an African friendly ecclesiology of Ubuntu can only be facilitated by the usage of the inculturation method of theology. This methodology accords due consideration to the African heritage with regard to their culture, spirituality and religious background emphasizing the values from traditional Africa that are helpful to Christian life and condemning those practices that are non-Christian in nature.

19 | This work is licensed under a Creative Commons Attribution 4.0 International License. 


\section{APA CITATION}

Oduor, P. L. O. (2021). Inculturation Methodology as the Medium towards the Formulation and Establishment of an African Ecclesiology of Ubuntu. East African Journal of Traditions, Culture and Religion, 3(2), 19-29. https://doi.org/10.37284/eajtcr.3.2.369

\section{CHICAGO CITATION}

Oduor, Peter Lee Ochieng. 2021. "Inculturation Methodology as the Medium towards the Formulation and Establishment of an African Ecclesiology of Ubuntu.”. East African Journal of Traditions, Culture and Religion 3 (2), 19-29. https://doi.org/10.37284/eajtcr.3.2.369.

\section{HARVARD CITATION}

Oduor, P. L. O. (2021) "Inculturation Methodology as the Medium towards the Formulation and Establishment of an African Ecclesiology of Ubuntu.", East African Journal of Traditions, Culture and Religion, 3(2), pp. 19-29. doi: 10.37284/eajtcr 3.2.369.

\section{IEEE CITATION}

P. L. O. Oduor, "Inculturation Methodology as the Medium towards the Formulation and Establishment of an African Ecclesiology of Ubuntu.”, EAJTCR, vol. 3, no. 2, pp. 19-29 Jul. 2021.

\section{MLA CITATION}

Oduor, Peter Lee Ochieng. "Inculturation Methodology as the Medium towards the Formulation and Establishment of an African Ecclesiology of Ubuntu." East African Journal of Traditions, Culture and Religion, Vol. 3, no. 2, Jul. 2021, pp. 19-29, doi:10.37284/eajtcr.3.2.369.

\section{INTRODUCTION}

An increasing interest in ecclesiology has emerged in the recent past that was triggered by the amazing shift of Christianity towards the global South, which saw areas that previously did not have a massive witness of Christian presence now becoming a phenomenon by the explosion of Christianity making these regions as the current centres of Christianity in present-day Christendom. The numerical changes in Christianity are striking enough, but beyond the simple demographic transition, there are countless implications for theology and religious practice as captured by Jenkins (2002, p. 6). We can attest to this by the quest to have an African Christian theology and most importantly the increasing desire for there to be an identical African ecclesiology that would be a signature of the African church. This task of formulation and establishment of an authentic African ecclesiology is a tall order that calls for strategy and consulted effort from theology practitioners and stakeholders on the approach and methodology of theology that enables African ecclesiology to gain maximum results in her practice and policy. The theological methodology of choice should have at its behest a quest towards the direction of double listening to the world around her and to God.

To achieve this end the ecclesiological conversation in Africa must have a sincere appreciation of the sociocultural political perspective of the African people and use the cultural perceptions in African tradition as accurate motifs to initiate the conversations ecclesiology in Africa is in dire need of. It is apparent that with regard to the cultural understanding of the African people Ubuntu takes a central place in the definition of the African people. It is from this understanding that we can ascertain that an ecclesiology that will thrive in Africa is an Ubuntu ecclesiology that uses the Ubuntu concept as a seed for the establishment of an African ecclesiology friendly to the African people. To achieve this end the benefit of the inculturation methodology of theology comes in handy and it is the interest of this study to explore the significance of the stated methodology as a medium of the formulation and establishment of an Ubuntu ecclesiology. In pursuant of our objective the study will seek to explore the understanding of Ubuntu in traditional Africa; the Inculturation theological method and the Ubuntu ecclesiology. The next step will be to elaborate on how Ubuntu ecclesiology is achievable by the means of steadfast engagement of the theological method of Inculturation. We shall finally submit our conclusion and recommendations.

\section{Understanding the Ubuntu Concept}

An understanding of the concept of Ubuntu is of paramount significance to establish an African ecclesiology of Ubuntu. Over time there seems to be 
a metamorphosis from a mere diction with a specific meaning towards a philosophy to capture the life of a people. It is of great importance to acknowledge that in as much as the origin of the word comes from Southern Africa; it seems to be a principle that governs the life and culture of the African people beyond Southern Africa. Archbishop Desmond Tutu has captured the concept of Ubuntu being more of a philosophy than a concept as it refers to celebrated virtues promoted in the African setting such as gentleness, compassion, hospitality, openness to others, vulnerability, availability and the understanding of our interconnectedness with others in our society according to Resane (2017, p. 93). Ubuntu regarding its concept and philosophy is 'conceptualized in some Idioms and proverbs such as:

\section{Umuntu ngumuntu ngabantu (IsiZulu)}

\section{Motho Ke moth ka batho (SeSotho)}

\section{Munhu тепи ратиsana pevanhu (sishona)}

\section{Umundu nimudu niunde wa andu (kikuyu)}

All these proverbs meaning one and the same thing that a person is a person by the people. This is according to the sentiments of Resane (2017, p. 95).

Mbigi (2000, p. 27) defines the literal meaning of Ubuntu as 'I am because we are- I can only be a person through my association with others. Inherent in this worldview is the capacity to influence the personality of an individual. Resane (2017, p. 96) could not be further from the truth in the sentiments of Ubuntu shaping one's conceptualizations including character and ethics. This is a philosophy that governs to a great extent the life of an African. Africans are gregarious people and their traditional way of living in large family units plays a tremendous part in their social adjustment and behaviour as is observed by Adeyemo (1979, p. 87). This was the ethos that defines the traditional life of the Africans. Mbiti (1972, p. 108) with all accuracy observes that in the traditional life, 'the individual does not and cannot exist alone except corporately. He owes his existence to other people, including those of past generations and his contemporaries'. For an African, the language of $\mathrm{I}$ is inadmissible as the accepted language is, 'we' or ours. Adeyemo (2009, p. 17) analyses correctly that no African lives alone, to an African there is no language such as 'me, myself and I' because we have a strong sense of community that borders on ethnicism. To the African, 'a man is simply part of the whole and the community must therefore make, create or produce the individual; for the individual depends on the cooperate group' in the words of Mbiti (1972, p. 108). The two basic tenets of the Ubuntu concept and philosophy relevant to our study are that of community and relationships.

\section{Inculturation Theological Method}

The initial stride in understanding the concept of inculturation is to have a definition of the term. We observe the general meaning then look at the narrow meaning with regard to its theological understanding. Inculturation can be defined as 'the ongoing dialogue between faith and culture or cultures' and more elaborate 'as the creative and dynamic relationship between the Christian message and a culture or cultures' as is captured by Shorter (2006, p. 11). The term is intended conceptually both to safeguard the integrity of the Gospel and to encourage sensitivity to various cultural contexts as is stipulated by Doyle (2012, p. 1). John Paul II in 1982 while repeating the sentiments of Paul vi in 1975 but with a sense of urgency that 'I have considered the church's dialogue with the cultures of our time to be a vital area, one in which the destiny of the world at the end of this twentieth century is at stake', and this process of dialogue is all that inculturation is about in the expression of Arbuckle (2010, p. 19). Bevans (2018, p. 1) evaluates that many theologians would say that there really is no such thing as 'theology'- a kind of 'one-size-fits-all,' universally applicable expression of 'faith seeking understanding,' rather they would say that the only kind of theology that exists is 'contextual theology'- theology, in other words, that is specific to a particular place, a particular time, and a particular culture. Bevans (2018) further asserts that theology is and must be contextual that is the attempt to understand Christian faith in terms of a context is truly a theological imperative.

\section{THE AFRICAN CULTURAL PERSPECTIVE}

From the understanding of inculturation conversation, we observe the continual emergence of the term culture in the practice of inculturation 
and therefore it is in the best interest of our study to elaborate on it further. Despite the wide submissions of its definition Tylor (1871, p. 1) is widely accepted as accurate that it is that complex whole which includes knowledge, belief, art, morals, law, custom and any other capabilities and habits acquired by man as a member of society. It is in this respect that Shorter (2006, p. 4) captures the sense of human society becoming the criterion of culture because culture is what a human being learns or acquires, as a member of society and comprises the learned aspects as opposed to the inherited aspects of human thinking and human behaviour. This takes us to the African culture as we ask the question: what are some elements that Africans learn or acquire as society members? Falola (2008, p. 1) observes from the broad cultural meaning that it incorporates values, beliefs, texts about belief and ideas, multiple daily practices, aesthetic forms, systems of communication (e.g., languages), institutions of society, a variety of experiences that capture Africans' way of life.... It has been argued that cultures, rather than 'culture' in a sense may convey a misleading notion of homogenous practices and values, is more appropriate in characterizing the diversity that is represented by Africa because with over eight hundred recognizable cultures and languages, we are confronted with various values, dialects, philosophies, and worldviews according to Falola (2008, p. 3).

In as much as it is true that Africa has a variety of cultures, Adeyemo (2009, p. 16) correctly acknowledges that the predominant African worldview is mystically anthropocentric and places human beings at the centre of the universe and makes the animals, plants, natural phenomena including invisible forces existing for the benefit of man. Lang (1994, p. 173) in like manner recognizes that since time is one of the natural givens that human beings can do little to alter, the dictum, 'I am because we are, and since we are, therefore I am,' serves as a most suitable key or heuristic tool for understanding African ontology, philosophy, and religion than time does. it is in this African notion of human brotherhood, or Ubuntu which described a quality of mutual responsibility and compassion that Nelson Mandela was brought up with as is expressed by Sampson (1999, p. 10). Broodryk (2002, p. 13-14) accurately captures the concept of Ubuntu as a comprehensive ancient African world view based on the values of intense humanness, caring, sharing, respect, compassion and associated values, ensuring a happy and qualitative human community life in a spirit of family. For an African, it is by belonging to the community that we become ourselves and the community is not opposed to the individual, nor does it simply swallow the individual up, it enables each individual to become a unique centre of shared life as is captured by Shutte (2001, p. 9). It is apparently clear that there can never be any conversation concerning African culture without the involvement of the Ubuntu concept. The tragedy is that missionaries were wrong to dismiss Ubuntu as they sought to establish Christianity in Africa based on European culture because Ubuntu has everything that could connect Africans with Christianity and help it make sense to African contexts as captioned by Joseph Mukuni, Josiah Tlou (2021,p.50).

\section{Inculturation Methodology in the Historical Development of African Theology}

The method of inculturation is one that is committed to ensuring that the gospel presentation and proclamation as well as the dogmas of Christian faith find their expressions in ways and means that are of help and valuable to the local Christian communities. This calls for an appreciation on the part of the person undertaking the theological process of the values and positive elements from the African cultures and religion that can facilitate an understanding from the part of the Africans of the Christian faith. It also springs from the understanding that there is some worth that the universal church can draw from the African narrative of culture and religious worldview. It came as a protest in the strongest terms against the perceived westernization of the Christian gospel that saw the packaging of the gospel in the European culture. This thought is clearly caught in the sentiments of the Pan African Conference of Third World Theologians that African theology must come to a place that it is understood in the context of African life and culture and the creative attempt of African people to shape a new future that is different from the colonial past and the neo-colonial present, it must as well be on the forefront of rejecting the prefabricate ideas of North Atlantic theology by defining itself according to the struggles of the people in their resistance against the 
structures of domination. They concluded that the theological task was that of creating a theology that arises from and is accountable to African people as was clearly expressed by Kofi Appiah-Kubi and Sergio Torres (1979, p. 193).

Martey (1993, p. 63) has described this process as that of 'Africanization' and traces its roots even beyond the decolonization era and was first introduced as a concept in the political arena. The World Council of Churches second assembly saw a strong need to Africanize the church so as to overtake the political advancement in certain areas where African leadership is an accepted feature of life. This is because many Africans identify Christianity with the white faces, and when they see many Europeans and Americans living lives contrary to what the European missionaries demanded from the African converts, they are left in a state of confusion in light of AACC (1962, p. 12). This endeavour of inculturation has been a long journey that Martey (1993, p. 64) seeks to capture dating back from the 1950s and 1960s that was captured when both Catholicism and Protestantism made daring efforts of reassessing Christianity from a new perspective. The Roman Catholics for instance according to a survey conducted in the 1960s attests to the fact that the main concern was that of "the Africanization of the church," where the church was to adapt herself to the African conditions. The prevailing challenge then was the lack of sufficiently numerous native clergy and a trained catholic laity. This called for a sense of urgency in the training of priests and lay folks to champion the Africanization agenda along with the desire to achieve an African re-interpretation of the faith, and the attempt to find an African theology as is correctly presented by Gallina (1969, p. 12-14).

The protestant on their part in the task of Africanization sought earnestly for the unity of the church and theological inquiry. The factor of ecclesiastical union could be best approached within the framework of the church confrontation with the world which was seen in a more radical fashion in Africa than in the West (Martey, 1993). This is the reason why there was an overwhelming rejection of the North Atlantic theology as being prefabricated and bankrupt in the 1963 inaugural assembly of the All-Africa Conference of Churches (1963, p. 38) held in Kampala that stressed the need for a more adequate and clear theology. This is the period that saw the emergence and coming into the light of prominent individual theologians who championed the agenda of calling the African church to formulate an indigenized theology. Leading players in this task included people like John S. Mbiti, Bolaji Idowu and many others.

The journey to Africanize Christianity has its long history and Kalilombe in his work on "Black Theology in D.F.Ford ed., (1989, p. 202) has critically observed that the idea of adaptation in vague at the time, the writers proclaimed the need to Africanize Christian doctrine, cult, pastoral practices and art basing them on African culture and religious traditions. This is an understanding spearheaded by Nyamiti that incumbent on African culture and religion there is inherent therein positive elements to facilitate the proclamation of the gospel, Martey (1993, p. 65) has observed that in an effort to re-express the Christian message with African idioms and conceptual tools, expressions such as adaptation, accommodation, incarnation and indigenization was employed by both the Catholic and Protestant theologians. It was from the mid-80s that the concept of inculturation was accepted in Africa and incorporated the concept of the incarnation of the Roman Catholics and indigenization of the protestant, thus becoming the common expression among African Catholics and Protestants as expressed by Martey (1993, p. 68). In this respect it is paramount to affirm that Ubuntu provides a faithful route for the contextualization of Christianity in Africa and African Christians having an understanding of their faith through lenses of Ubuntu, understand that they belong to a worldwide fellowship of many who have also been made to be persons with Ubuntu in Christ as is correctly expressed by Joseph Mukuni, Josiah Tlou (2021, p. 50)

\section{Nyamiti's Approach to Inculturation}

Nyamiti gives us a three-fold process of approaching the inculturation methodology as being synthetic method; comparative method serving the analogical method; and lastly analogical African thinking and Nyamiti's Theological Method all which are accurately studied by Vähäkangas (1999, p. 146-214). Nkansah-Obrempong (2017) analyses that the synthetic method captures Nyamiti's 
understanding of reality that is optimistic towards revelation and relates closely to trinity because he feels the trinity has been marginalized in traditional theology, because of the philosophical approach, which tends to discuss the theme of God separately from the Trinity. His synthetic approach tries to connect theological views from above and below. However, his primary point of departure is that of above. The view from above sets the limits for the approach from below and thus the resulting theology is from above, starting from metaphysical questions. The synthetic methods work on the assumption of absolutizing "truth-matter" contained in theologies, dogmas, and other magisterial teachings." The limitations to this approach are highlighted as follows: logic is not the same in all cultures; understanding of revelation is too optimistic; who determines what is logical and heretical? Worldviews are different- this can lead to the subordination of theologies.

In the comparative method, Vähäkangas (1999, p. 166-179) observes that Nyamiti uses it as a stepping-stone towards analogy. As a starting point of the inculturation process, comparison simply means pointing out the similarities and differences between the items scrutinized both on the side of African traditional cultures as well as Christianity. Influenced by Mircea Eliade comparison was central to Eliade's study of religion. Eliade also shows the interconnectedness of religious phenomena; this is reflected in Nyamiti's synthetic approach. Nyamiti's approach however defines the absolute truth-values contained in the religious and cultural phenomena. The method contains a number of stages. The meaning of the phenomenon suggested by the people of that culture- (emic approach); Its sociological, functions meanings (etic approach); Its position in the structure of the whole culture- (organic whole); Its outward manifestations; its constitutive components; its connotations, etc.; Purge the African phenomenon from magic, superstition and modified it to compare with Christian teaching and Western science.

In the analogical method, Nyamiti applied analogy to the ancestor and the immanent Trinity as the basis of Christ's Ancestor-ship as he affirms that Christ is an Ancestor. In this affirmation, it does not mean that it is an addition to the honorary titles for Christ but that Christ is really an ancestor. Ancestor-ship is a paradigm and root metaphor in Nyamiti's theology. We intend to appreciate this theological approach because of its appreciation of the values that are inherent in African tradition and religion and use the same as a starting point for any theological dialogue in theological reflections in Africa. This is a step forward with regard to the theological establishment in our continent that was previously resisting everything African and hostile to African traditions. Resultantly the theological practice in the continent was seemingly irrelevant and failed the task of addressing pertinent issues raised and of concern to the indigenous people. This made the theology in place to lack the moral authority to correct malpractices within the cultures of the Africans. The first step of the presentation of the Christian message should have incorporated a familiarization with the African culture to enable the presenter to have a more positive engagement with the culture as opposed to having a formed opinion of everything that is African.

Nyamiti submits a fourfold approach that facilitates the process of the construction of an African Christian Theology: pastoral; apologetical; pedagogical; and comparative approaches, the three approaches (pastoral, apologetical and pedagogical) serve as different albeit particularly similar horizons in the process of employing the fourth approach namely comparison according to Vähäkangas in Edward P. Antonio (2006, p. 78). Vähäkangas (Edward P. Antonio, 2006) further alludes that the key difference of comparison with the other three is in the sense of being more of a method as opposed to an approach and is a method of comparing different doctrinal themes, religions, or theologies with each other with an aim of deepening the understanding of certain parts of theology by comparing them to others or other types of religious thinking in an effort to demonstrate how all parts of theology are interconnected.

\section{AFRICAN ECCLESIOLOGY OF UBUNTU}

An African ecclesiology of Ubuntu falls within the cluster of global ecclesiology that according to Kärkkäinen (2002, p. 163) is in reference to theologies outside the West. It is referred to as an African ecclesiology because it is steadfast in her quest to pursue an atmosphere of dialogue between the African culture that has a dominance of the 
concept of Ubuntu to the Christian ecclesiological discourse. The underlying issue is to demonstrate through the utilization of the inculturation methodology, the benefit of Ubuntu that is an African conceptual framework in theological articulation and most specifically conversations of African ecclesiology. We wish to accomplish this by identifying strong variables incumbent on the Ubuntu to express the practical analysis and management of Inculturation towards an Ubuntu ecclesiology. The variables that we wish to have ecclesiology inculturate from the African dimension include community and relationship. With regard to the community, we focus on the practice of shared life and mutualism incumbent on Ubuntu towards a design of Christian praxis. Relationship will take us towards the trajectory of architectural organisation of the community with elements such as families and clanism as a pointer towards internal architecture.

\section{Ubuntu Ecclesiology as a Community-Oriented Ecclesiology}

Resane (2017, p. 97) affirms that one of the core concepts of Ubuntu is the philosophical ideology that individualism is self-fatalism and the emphasis of the denial of the proponent of the doctrine that every happening is pre-determined but that every happening directed towards an individual has a bearing on the entire community. This is in agreement with the expression that Ubuntu brings to the West a new understanding of life that encourages people to care for one another to go back to communities and move away from individualism that is at the centre of many social ills going on in Western cultures as is captured by Joseph Mukuni, Josiah Tlou (2021, p. 50). It is this interdependence of humanity that is intrinsic to the Ubuntu philosophy that provides a critique and contrast to the individualism celebrated by the Western culture and the contemporary enterprenual notion of the self (Larsen 2015,p.255). James Ogude (2019, p. 91) could not agree further with the critique of the liberal individualism in contemporary African thought as not a rejection of the value of individuality but rather an alternative way of pursuing it in the human community. Swanepoel $(1998,393)$ further affirms that Ubuntu is opposed to individualism and insensitive competitiveness but is not comfortable with the kind of collectivism that stresses the importance of the social unit to the point of depersonalising the individual. This talks much about the lifestyle of the traditional African people that had a strong impact on each one of them.

The variable of interdependence is paramount in the construction of an African ecclesiology by virtue of the strong advocacy expressed in the scriptures. The concept of koinonia is to a large extent characterized by a lifestyle of sharing as is stated by Resane (2017, p. 110). Battle (2009, p. 58) in the same breath acknowledge that just as the creation narrative accounts that it is not good for man to be alone the Africans say that a person is a person through other persons and we are meant to be interdependent and to live in fellowship and in koinonia. This is the same model that was reminiscent of the apostolic church in the Book of Acts. This is captured in Acts 4:32 which states that "All the believers were one in heart and mind. No one claimed that any of their possessions was their own, but they shared everything they had." Kisau in the African Bible Commentary by Tokunboh Adeyemo- General Editor (2006, p. 1334) on the text comments that the sense of extraordinary sharing reminiscent of this newfound prophetic community was enabled by their posture of oneness of purpose. He further observes that the same posture shifted the community away from individualism as they resisted the temptation of claiming that their processions were their own private property as is accurately covered in Tokunboh Adeyemo- General Editor (2006).

Ryken (2001. p. 115) elaborates further that koinonia went beyond the sense of belonging to a community and included the dimension of having an obligation to care for other community members. The strongest correlation is expressed by Resane (2017, p. 110) that Ubuntu is all about sharing one's life in and for the community a feature that is similar to the New Testament ecclesia, where believers' togetherness was marked by having everything in common. This practice of sharing expressed the emphasis of this early church to the element of shared life that was in another way a means of witnessing by virtue of its portrayal of a sense of oneness that was an item in the prayer of Jesus for his followers and a significant demonstration of the fact that Jesus has truly come from the Father and the abundance of God's grace enabled both the 
witness and the unity of the community as is captured in Kisau's comment in Tokunboh Adeyemo- General Editor (2006).

This is a critical concept with regard to the Communion ecclesiology within the framework of Ubuntu as an internal value of African ecclesiology with a relevant leadership structure and order to facilitate a certain way of life to enhance the flow of grace to all the members of the church community. African Christians should come to a place of commonality as an expression of unity of faith and in the knowledge of Christ to fulfil the plan and purpose God has for them. This principle of shared life captures a status of life produced by the mature functionality of a Christian community of saints with common flow of grace and government. This is what will enable us to have one DNA as a body because the whole body has one DNA and therefore, we have the same knowledge, same understanding, and life flowing through the entire ecclesiastical community. This is an ecclesiology that has as its starting point an ordination from God, who has ordained us to be part of this community. It is the starting point for us to come to a place of oneness and building a united body of Christ thus the definition begins with the definition of God because it is impossible to have an accurate sight of ecclesiology from the fallen state of self. It is the coming up to that elevated place of being seated together with God that will bring us to a place of oneness in heart and mind having the same view as God and to seamlessly collaborate with God's mind.

\section{Ubuntu Ecclesiology as a Relational Ecclesiology}

Relationships in traditional Africa were accorded high status as the glue that held the society together. This places the task of establishing strong relationships as a precursor for the establishment of strong communities. Pieter Hendrik Coetzee, A. P. J. Roux (2002, p. 197) asserts that in traditional Africa, stress is mainly due to a strained relationship either with one's spiritual agents or with other persons within one's community. It could also be due to a feeling of guilt arising from a breach of communal norms. The significance of the concept of relationship is explained in unequalled terms by Josephat Obi unequalled (2003, p. 250) that African traditional worldview implies two basic beliefs: the unity of all things (supernatural, animate, and inanimate) and ordered relationship among all beings in the universe. The relational dimension of the concept of Ubuntu is largely envisioned in structures such as family, both nucleus and extended that was a critical institution in the community formation. We capture some of the major functions of the family included socialization, informal education and the transmission of cultural values and the critical expectation of the society was the prospect of families rising to the occasion to help perform the responsibility of passing on the cultural heritage, like the basic values of Ubuntu as is captured by Broodryk (2005, p. 111).

Shutte (2001, p. 100) captures the family as the living cell of society and is quick to emphasize that a society characterized by Ubuntu will be one that is keen to make good family life possible because it has the responsibility of fulfilling its role as the fundamental source of education for the citizenry of that society. So significant was the matter that Smit (1999, p. 27) emphasizes that if we can translate Ubuntu into respect, compassion, care for and commitment to the single individual and the community, we could reinstate marriage and family as key units in our society. In line with the concept of Ubuntu, Rey (1997, p. 166) affirms that a family can be extended to include nonconsanguineal relatives in the community ... with different members of the extended family system, with the grandmother assuming most of the nurturing functions. In agreement Shutte (2001, p. 101) comments that although the community of mother, father and child is the nucleus it is not the complete family because the mother and the father are also children of their parents and they do not cease to become so when they become parents themselves. Therefore, we can authoritatively ascertain that the African family is defined in very broad terms and embraces far more than the nuclear family of parents and children because anyone with whom one shares blood ties, whether close or distant is regarded as part of one's family thus family includes brothers and sisters, uncles and aunts, cousins and nephews as far back as anyone can remember as is expressed by Soungalo in Tokunboh Adeyemo- General Editor (2007, p. 1204). 
The scripture is also keen to express the church using the analogy of a family of God. Soungalo in Tokunboh Adeyemo- General Editor (2007) correctly puts it that within the family and community that is the church, we should find plenty of evidence of the moral strengths of African family culture: solidarity, hospitality, joy and the like because at the suffering of an individual member all the members should suffer because there is a sense of members caring for one another as they work together in coorperation for the common interest (Rom 12:4-18; $1^{\text {st }}$ Cor 12:12-30). Ngewa in his commentary of Gal. 3:27-28 in Tokunboh Adeyemo- General Editor (2007) expresses that in the early church, baptism signified identification with Christ to such an extent that it was almost as if they were 'wearing' Christ. Their lives were taking on the characteristics, virtues and intentions of Christ and because of this change, the differences between them had disappeared, for now, they all looked alike as members of Christ's family with categorizations like race, status, and gender are no longer important.

Waruta in his critical assessment of alternative forms and structures towards an African Church in J.N.K. Mugambi \& Laurenti Magesa (1990, p. 37) observes that the indigenous churches were the best examples of the dynamism of African spirituality that as opposed to the Orthodox Christian churches, the indigenous churches experienced the presence of God not through some documents or traditions but in the context of their community life and existential realities with little regard or reference to external validating authorities. The kinship system of the African people being utilized in the development of communities of faith where no one is left without genuine, emotional, and physical support. Waruta in J.N.K. Mugambi \& Laurenti Magesa (1990, p. 38) does not shy away from highlighting the main weakness as a tendency to drift towards ethnocentricism and inadequacies of fitting into the universal dimension of the church. This was because their world if not their God was too small and limited to their group's worldview. This has been the strong critique that Ubuntu ecclesiology has had to deal with because of the understanding of community within the Ubuntu framework being limited to an ethnic orientation. However, it is important to observe that Ubuntu ecclesiology aligns herself to Galatians 3:28 that disqualifies all existing categorizations as long as the basic requirement of adorning Christ is achieved and propels us towards a trajectory of unity.

Walligo in J.N.K. Mugambi \& Laurenti Magesa (1990, p. 125) as he submits a theological conclusion on the subject of the "African clan as a model of African Church' asserts that the koinonia practiced in the early church is nothing other than familial relationship where every believer was a brother or sister to the other. This familial bond weakened and was substituted with institutional model as the church developed but there is an awakening of this familial model approach through small groups, charismatic groups and others. Walligo in J.N.K. Mugambi \& Laurenti Magesa (1990) further analyses the important consequences of the clan system model of the church as a modification of the ways in which church leadership is chosen; the administration and organization of the local church; emphasis on ecumenism where all God's people are seen as true relatives; undertake inculturation in all aspects; and the promotion of the active role of the laity, women and children in an effort to realize clear work division. All of which express the centrality of communion and everything done to strengthen it. This he observes is the very best that Africa can offer the Universal church which is an offer that stresses human dignity and equality of each and every member and in this sense the church Universal is seen as the Mother of all clans, never excluding any but always embracing.

\section{CONCLUSION AND RECOMMENDATIONS}

It is apparent that inherent in African Tradition and specifically the concept of Ubuntu is a wealth of resources that if unearthed can be of enormous supply in the task of African Christianity. Our interest was to capture the understanding of Ubuntu and study how the usage of the inculturation method would midwife an African ecclesiology of Ubuntu. We have observed the contribution of inculturation methodology towards the historical development of African theology. To facilitate our understanding of inculturation methodology we studied the approach of Nyamiti in the undertaking of the same. We were able to administer a practical dimension of the inculturation methodology by advancing the establishment of an African ecclesiology of Ubuntu by the utilization of the concept of Ubuntu to 
demonstrate the African conceptual framework that can indeed be of use in the articulation of an ecclesiology that is relevant to the African world. This can only be realized if we embrace the inculturation methodology as a medium towards the formulation and establishment of an African ecclesiology of Ubuntu. We further recommend studies of Ubuntu ecclesiology and her influence on church polity, polemics and praxis.

\section{REFERENCES}

(AACC), A. A. (1963). Drumbeats from Kampala. (p. 38). London: Lutterworth.

Adeyemo, T. (1979). Salvation in African Tradition. Nairobi, Kenya: Evangel Publishers House.

Adeymoh, T. (2009). Africa's Enigma and Leadership Solutions. Word Alive Publishers.

All Africa Churches Conference. (1962). Africa in Transition: The Challenge and the Christian Response. (p. 12). Geneva: WCC.

Arbuckle, G. A. (2010). Culture, Inculturation, and Theologians: A Postmodern Critique. Collegeville, Minnesota: Liturgical Press.

Battle, M. (2009). I in You and You in Me. New York: Seasbury Publishing.

Bevans, S. (2018). Essays in Contextual Theology. Leiden, Boston: Brill.

Broodryk, J. (2002). Ubuntu: Life lessons from Africa. Pretoria: Ubuntu School of Philosophy.

Broodryk, J. (2005). Ubuntu Management Philosophy. Randburg: Knowres Publishing.

D.F.Ford ed. (1989). The Modern Theologians: An Introduction to Christian Theology in the Twentieth Century. New York/London: Basil Blackwell.

Doyle, D. M. (2012). The Concept of Inculturation in Roman. eCommons; University of Dayton, 115.

Edward P. Antonio. (2006). Inculturation and Postcolonial Discourse in African Theology: Volume 14 of Society and politics in Africa. New
York/ Washington, D.C./ Baltimore/ Bern Frankfurt am Main/Berlin/ Brussels/ Vienna/ Oxford: Peter Lang.

Falola, T. (2008). The Power of African Cultures. University Rochester Press.

Gallina, E. (1969). Africa Present: A Catholic Survey of Facts and Figures, trans. Dorothy White. London: Geoffrey Chapman.

J.N.K. Mugambi \& Laurenti Magesa . (1990). The Church in African Christianity: Innovative essays. Nairobi: Initiative Publishing.

James Ogude ed. (2019). Ubuntu and the Reconstitution of Community:World Philosophies. Bloomington: Indiana University Press.

Jenkins, P. (2002). The Next Christendom: The coming of global Christianity. Oxford: Oxford University Press.

Joseph Mukuni, Josiah Tlou. (2021). Understanding Ubuntu for Enhancing Intercultural Communications. Hershey, PA, USA: IGI Global.

Josephat Obi Oguejiofor. (2003). Philosophy, Democracy and Responsible Governance in Africa: Volume 1 of Studies in African philosophy. Lit.

Kalilombe, P. (1977). Building Christian Communities. Lumen Vitae, 185.

Kärkkäinen, V.-M. (2002). An Introduction to Ecclesiology: Ecumenical, Historical \& Global Perspectives. Downers Grove, IL: InterVarsity Press.

Kofi Appiah-Kubi and Sergio Torres, eds. (1979). African Theology En Route. Maryknoll, N.Y.: Orbis Books.

Lang, P. (1994). Being Human in Africa: Towards an African Christian Anthropology. New York: Peter Lang Publishing.

Marianne Larsen. (2015). International Service Learning: Engaging Host CommunitiesVolume 17 of Routledge Research in International and

28 This work is licensed under a Creative Commons Attribution 4.0 International License. 
Comparative Education. New York and London: Routledge.

Martey, E. (1993). African Theology: Inculturation and Liberation. Maryknoll, N.Y.: Orbis Books.

Mbigi, L. (2000). In Search for the African Business Renaissance. Randburg, South Africa: Knowledge Resources

Mbiti, J. (1972). African Religions and Philosophy. New York: Praeger.

Nkansah-Obrempong, J. (2017). Lectures in theological methods PHD. Seminar. Africa International University, Nairobi: Kenya: unpublished.

Pieter Hendrik Coetzee, A. P. J. Roux. (2002). Philosophy from Africa: A Text with Readings. Oxford University Press.

Resane, K. T. (2017). Communion Ecclesiology: In a racially polarized South Africa. Sun Press.

Rey, C. D. (1997). Contemporary Issues in Human Development: A South African Focus. International Thomson Publishing.

Ryken, P. G. (2001). The Communion of Saints: Living in Fellowship with the People of God. Phillipsburg, NJ: P \& R Publishing.

Sampson, A. (1999). Mandela: The authorized biography. London: Harper Collins Publishers.

Shorter, A. (2006). Towards a Theology of Inculturation. Eugene, Oregon: Wifp and Stock Publishers.

Shutte, A. (2001). Ubuntu: An Ethic for a New South Africa. Cluster Publications.

Smit, J. H. (1999). Ubuntu in a Christian Perspective: Issue 374 of Wetenskaplike bydraes van die PU vir CHO.: Instituut vir Reformatoriese Studie. Potchefstroom University for Christian Higher Education, Institute for Reformational Studies.

Swanepoel, B. (1998). South African Human Resource Management: Theory and Practice. Juta \& Company, Limited,
Tokunboh Adeyemo- General Editor. (2006). African Bible Commentary. Nairobi: Word Alive Publishers.

Tylor, E. B. (1871). Primitive Culture: Researches Into the Development of Mythology, Philosophy, Religion, Art, and Custom, Volume 1. London: John Murray.

Vähäkangas, M. (1999). In Search of Foundations for African Catholicism: Charles Nyamiti's Theological Methodology. Leiden: Boston: Koln: Brill 